Prepared in cooperation with the Arkansas Natural Resources Commission

\title{
Effects of Recent Climate Variability on Groundwater Levels in Eastern Arkansas
}

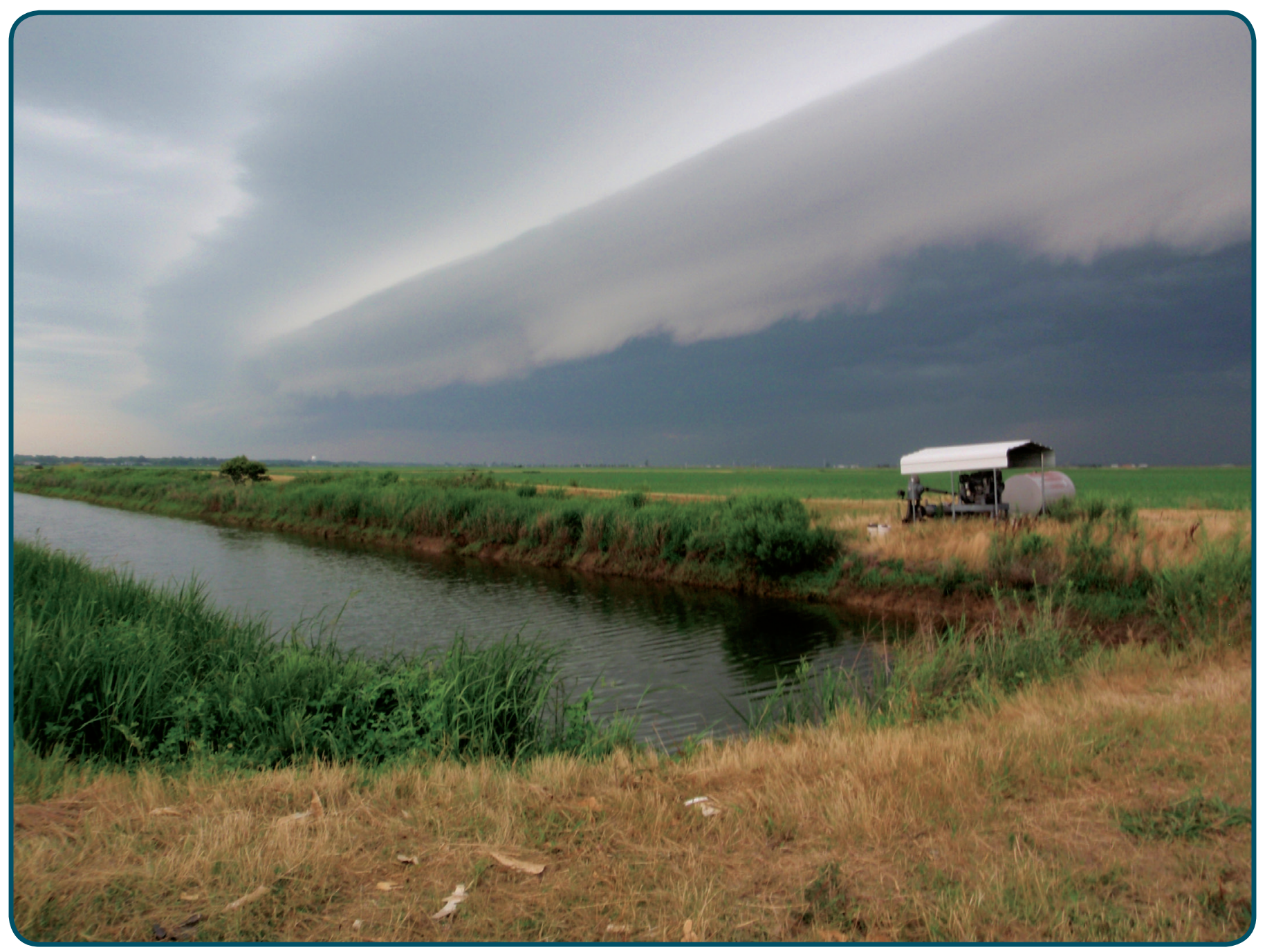

Scientific Investigations Report 2012-5258 
Cover: Approaching storm wall cloud, Prairie County, Arkansas, May 25, 2011 (photograph by John B. Czarnecki, U.S. Geological Survey). 


\section{Effects of Recent Climate Variability on Groundwater Levels in Eastern Arkansas}

By John B. Czarnecki and T.P. Schrader

Prepared in cooperation with the Arkansas Natural Resources Commission

Scientific Investigations Report 2012-5258 


\section{U.S. Department of the Interior \\ KEN SALAZAR, Secretary \\ U.S. Geological Survey \\ Marcia K. McNutt, Director}

U.S. Geological Survey, Reston, Virginia: 2013

This and other USGS information products are available at http://store.usgs.gov/
U.S. Geological Survey
Box 25286 , Denver Federal Center
Denver, CO 80225
To learn about the USGS and its information products visit http://www.usgs.gov/
1-888-ASK-USGS

Any use of trade, product, or firm names is for descriptive purposes only and does not imply endorsement by the U.S. Government.

Although this report is in the public domain, permission must be secured from the individual copyright owners to reproduce any copyrighted materials contained within this report.

Suggested citation:

Czarnecki, J.B., and Schrader, T.P., 2013, Effects of recent climate variability on groundwater levels in eastern

Arkansas: U.S. Geological Survey Scientific Investigations Report 2012-5258, 17 p. 


\section{Contents}

Abstract
Introduction .16
Methods
Water-Level Monitoring Network
Effects of Recent Climate Variability on Groundwater Levels
Water Use and Conservation
Groundwater Depletion
Long- and Short-Term Water-Level Changes: A Case for Continuous Monitoring
Future Water-Level Monitoring
Summary feferences Cited

\section{Figures}

1. Graph showing annual precipitation for Adams Field in Little Rock, Arkansas, for the period 1878 to 2010

2. Maps showing four-year water-level difference in the Mississippi River Valley alluvial aquifer in eastern Arkansas (A) 2004-8, and $(B)$ 2006-10

3. Map showing active water-level monitoring network in Arkansas County,

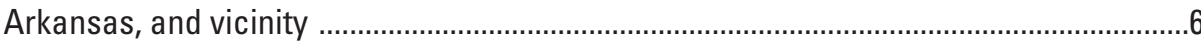

4. Histogram of differences in water-level altitudes for the alluvial aquifer in eastern Arkansas

5. Map showing percentage of water use in $\mathbf{2 0 0 8}$ from the alluvial aquifer in eastern Arkansas .8

6. Graph showing groundwater use in Arkansas County, 1965 to 2009 .................................9

7. Photograph showing tailwater recovery reservoir in Prairie County .................................

8. Photograph showing polypipe used for irrigation of a soybean field .............................10

9. Map showing simulated altitude of the bottom of the northern part of the alluvial aquifer from the model of Czarnecki ....................................................................11

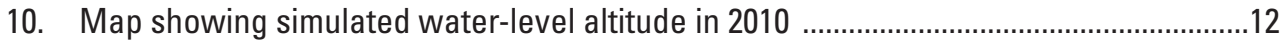

11. Map showing simulated thickness for the Mississippi River Valley alluvial aquifer, 2010

12. Graph showing periodic depth-to-water measurements made in Arkansas County well 04S03W32BCB1 completed in the alluvial aquifer, 1937 to 2010

13. Graph showing continuous depth-to-water measurements made in Arkansas County well 03S04W03DCA16, completed in the alluvial aquifer, 2000 to 2011

14. Hydrograph of Arkansas County well 04S05W05ACC1 completed in the Sparta aquifer showing substantial decline in water levels from 1948 to 2010 


\section{Conversion Factors}

\section{Inch/Pound to SI}

\begin{tabular}{|c|c|c|}
\hline Multiply & By & To obtain \\
\hline \multicolumn{3}{|c|}{ Length } \\
\hline inch (in.) & 2.54 & centimeter $(\mathrm{cm})$ \\
\hline inch (in.) & 25.4 & millimeter $(\mathrm{mm})$ \\
\hline foot $(\mathrm{ft})$ & 0.3048 & meter $(\mathrm{m})$ \\
\hline mile (mi) & 1.609 & kilometer (km) \\
\hline \multicolumn{3}{|c|}{ Area } \\
\hline square mile $\left(\mathrm{mi}^{2}\right)$ & 259.0 & hectare (ha) \\
\hline square mile $\left(\mathrm{mi}^{2}\right)$ & 2.590 & square kilometer $\left(\mathrm{km}^{2}\right)$ \\
\hline \multicolumn{3}{|c|}{ Volume } \\
\hline acre-foot (acre-ft) & 1,233 & cubic meter $\left(\mathrm{m}^{3}\right)$ \\
\hline acre-foot (acre-ft) & 0.001233 & cubic hectometer $\left(\mathrm{hm}^{3}\right)$ \\
\hline \multicolumn{3}{|c|}{ Flow rate } \\
\hline inch per year (in/yr) & 25.4 & millimeter per year (mm/yr) \\
\hline foot per year (ft/yr) & 0.3048 & meter per year (m/yr) \\
\hline million gallons per day (Mgal/d) & 3.7853 & million liters per day $(\mathrm{ML} / \mathrm{d})$ \\
\hline
\end{tabular}

Vertical coordinate information is referenced to the National Geodetic Vertical Datum of 1929 (NAVD 29).

Horizontal coordinate information is referenced to the North American Datum of 1983 (NAD 83).

Altitude, as used in this report, refers to distance above the vertical datum. 


\title{
Effects of Recent Climate Variability on Groundwater Levels in Eastern Arkansas
}

\author{
By John B. Czarnecki and T.P. Schrader
}

\begin{abstract}
Water-level fluctuations in wells completed in the Mississippi River Valley alluvial aquifer in eastern Arkansas were compared to variability in annual precipitation, an indicator of climate variability. The wettest year on record in Little Rock, Arkansas, occurred in 2009 with 81.79 inches of precipitation compared to an average of 47.1 inches per year. In contrast, 2005 and 2010 were the 7th and 14th driest years on record with 34.55 and 36.52 inches per year, respectively. This variability in precipitation was reflected in water-level altitude changes between 2004 and 2008 and 2006 and 2010. Generally, drier conditions between 2004 and 2008 led to an average decline in water levels of 1.62 feet, whereas wetter conditions between 2006 and 2010 led to an average rise in water levels of 1.36 feet. Drier periods likely resulted in less recharge compared to wetter periods. Groundwater use from the alluvial aquifer peaked in 2000 and has since declined, in part, because of conservation measures and substantial reduction in aquifer saturated thickness. Groundwater-flow model results showed some areas of the alluvial aquifer simulated as dry in 2010 , indicating a reduced capacity of the alluvial aquifer to produce water in those areas. Additional factors affecting groundwater use include the types of crops grown in an area and the availabitiliy of crop subsidies. Real-time continuous water-level measurements in wells allow for a more accurate assessment of the effect of variability in precipitation and water use than periodic waterlevel measurements.
\end{abstract}

\section{Introduction}

Arkansas experienced wide extremes in climate variability during the period of 2005 to 2010 , recording the largest annual precipitation ever recorded in the State (100.05 inches [in.]) in 2009 (National Weather Service, 2012). Many weather stations across the State reported between 80 to 90 in. of rainfall in 2009. For comparison, the average annual precipitation in Little Rock, Arkansas for the period 1878 to 2010 was 47.1 in. (fig. 1). In contrast, 2005 and 2010 were the 7 th and 14th driest years on record in Little
Rock with 34.55 and 36.52 in., respectively; both tied as the hottest years ever recorded in Arkansas (National Oceanic and Atmospheric Administration, 2011). The wettest year on record in Little Rock (2009) occurred between these dry years, with a total of 81.79 in. Fifteen out of a total of 60 National Oceanic and Atmospheric Administration weather stations within the State ranked 2009 as the wettest year on record (National Weather Service, 2012).

Extremes in annual precipitation rates may lead to greater variability in groundwater-recharge rates and water use, particularly in the agricultural areas in eastern Arkansas that rely heavily on groundwater produced from the Mississippi River Valley alluvial aquifer (hereafter referred to as the alluvial aquifer). Are the effects of climate variability discernable in measured water levels in wells?

The purpose of this report, which was prepared in cooperation with the Arkansas Natural Resources Commission, is to attempt to answer this question by reviewing water-level and water-use data in eastern Arkansas in the context of climate variability reflected by changes in annual precipitation. The report also reviews the benefits of continuous water-level monitoring as well as factors affecting water use. The period for precipitation data extends back to 1878 , and water-level altitude data extend back to 1937 . Emphasis was placed on water-level changes and annual precipitation from spring 2004 through spring 2010 in the alluvial aquifer. Because conservation measures and reduction in aquifer saturated thickness can have effects on water use (and therefore water levels), the report discusses these confounding factors related to the analysis of the effects of climate variability on groundwater levels.

\section{Methods}

Precipitation data were compiled from the National Weather Service (2011) for Adams Field at Little Rock National Airport in Little Rock, Arkansas, and presented as annual totals for the period 1878 to 2010. Adams Field precipitation data were used because that station has the longest continuous dataset and is located on the west-central edge of the alluvial aquifer. Average annual precipitation was 


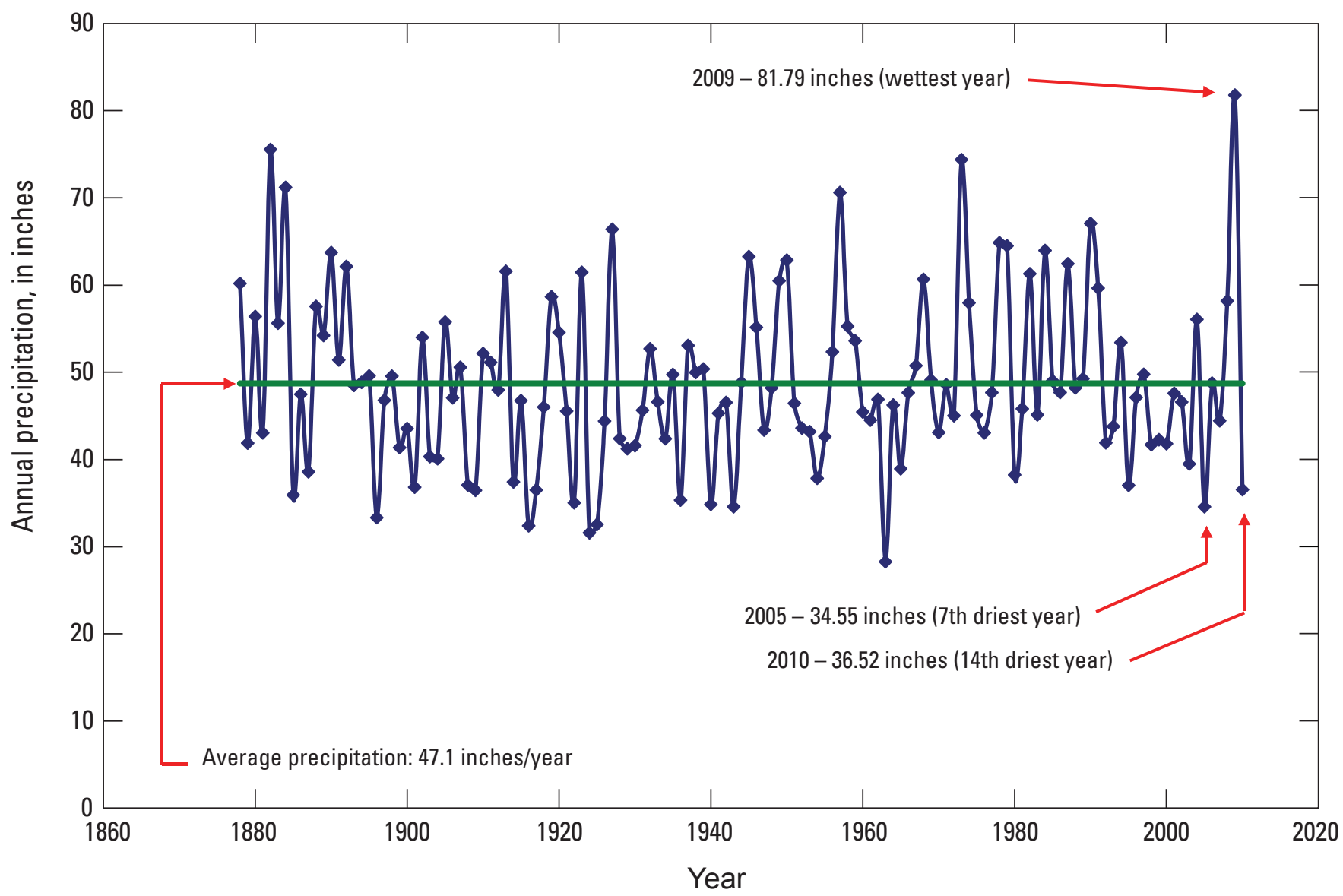

Figure 1. Annual precipitation for Adams Field in Little Rock, Arkansas, for the period 1878 to 2010 (National Weather Service, 2011). 
calculated for that dataset to compare against extreme amounts for the period 2004 through 2010. Annual precipitation amounts were sorted and ranked relative to the wettest and driest years.

Water-level data from the U.S. Geological Survey National Water Information System (NWIS) from 659 wells in eastern Arkansas were used to compute spatial and temporal changes in water-level altitude within the alluvial aquifer in eastern Arkansas from 2004 to 2008 and from 2006 to 2010 (fig. 2). The alluvial aquifer in Arkansas defines the extent of the study area. Hydrographs showing water-level altitude plotted against time were compiled for three wells to illustrate changes in water levels and to compare the temporal resolution provided by continuous water-level daily averages compared to periodic measurements made every other year in the spring. As an example of the information obtained in the study area, a screen capture of the active water-level-data collection network in Arkansas County was downloaded from the internet to show the locations of wells for which hydrographs were obtained. Included in the download were: (1) realtime wells from which hourly water-level measurements are downloaded to the internet every 6 hours; (2) continuous wells from which hourly water-level measurements are made automatically but require site visits to retrieve the data; and (3) periodic-measurement wells are measured manually using an electric tape at intervals that typically recur every other year in the spring prior to the irrigation season. Well locations are depicted (fig. 2) by colored points that represent the most recent water level at the time of the download as it occurs within the percentile class for all the measurements at a well.

Water-use data were compiled by county for the alluvial aquifer. Total water use from the alluvial aquifer in 2008 was provided through the Aggregate Water-Use Data System (AWUDS) (U.S. Geological Survey, 2012).

\section{Water-Level Monitoring Network}

The U.S. Geological Survey (USGS) monitors water levels in about 1,100 water wells throughout Arkansas in conjunction with the Arkansas Natural Resources
Commission, Arkansas Geological Survey, Union County Conservation District, and U.S. Department of Agriculture Natural Resources Conservation Service. Water levels from 659 wells completed in the alluvial aquifer were measured during the spring prior to the irrigation season to allow the water level in a well to stabilize and to better reflect conditions within the aquifer. Arkansas County (fig. 3) is one of several areas in the State that has experienced substantial declines in water levels because of groundwater pumping for irrigation (Schrader, 2010). Periodic and continuous water levels are monitored as part of the USGS water-level monitoring network.

\section{Effects of Recent Climate Variability on Groundwater Levels}

Between 2004 and 2010, water levels generally declined and then rose similar to annual precipitation (fig. 1). Water-level change maps generated using waterlevel data collected 4 years apart (Schrader, 2010) are shown in figure 2. Such maps are useful in observing regional trends in water levels that might correlate with changes in recharge and water-use rates. Water levels decreased an average of $1.62 \mathrm{ft}(\mathrm{ft})$ in eastern Arkansas with a median value of $2.00 \mathrm{ft}$ between 2004 and 2008, in part, as a result of the small amount of precipitation in 2005. Water levels rose an average of $1.36 \mathrm{ft}$ with a median value of $0.82 \mathrm{ft}$ between 2006 and 2010, resulting from the record amount of precipitation in 2009. From 2004 to 2008, water levels in most wells decreased 0 to $6 \mathrm{ft}$, whereas from 2006 to 2010, water levels in most wells increased 0 to $4 \mathrm{ft}$ (fig. 4). The average increase in water levels of about $3 \mathrm{ft}$ between dry (2004 to 2008) and wet (2006 to 2010) periods represents an approximate increase in groundwater storage of about 10 million acre-ft, assuming a specific yield of 0.3 and an area covered by the alluvial aquifer of 17,000 square miles $\left(\mathrm{mi}^{2}\right)$. Available water-level data were sufficient to show that water-level change on a regional scale was affected by climate variability. 


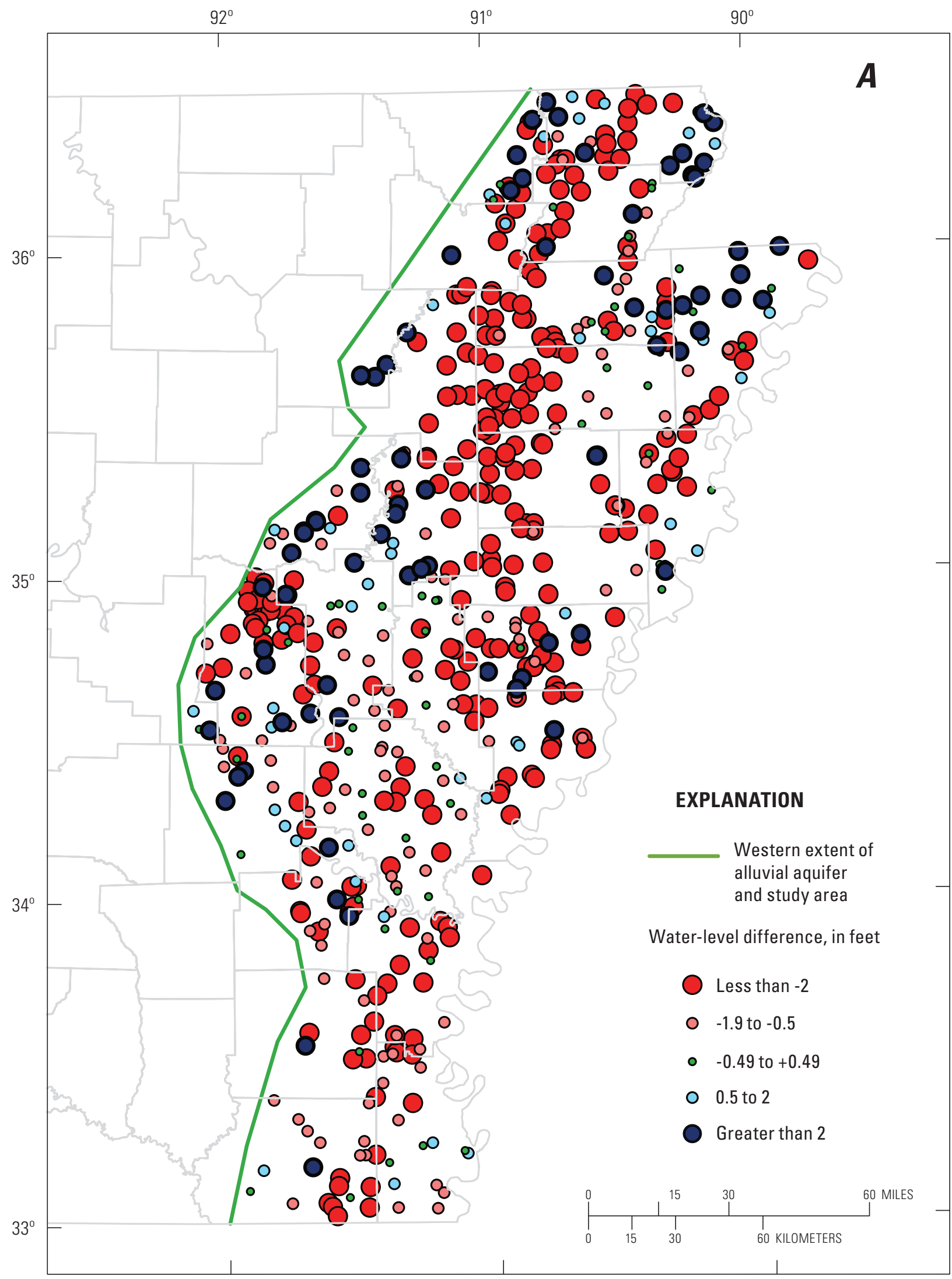

Base from U.S. Geological Survey digital data, 1:100,000

Figure 2. Four-year water-level difference in the Mississippi River Valley alluvial aquifer in eastern Arkansas $(A)$ 2004-8, and $(B)$ 200610. 


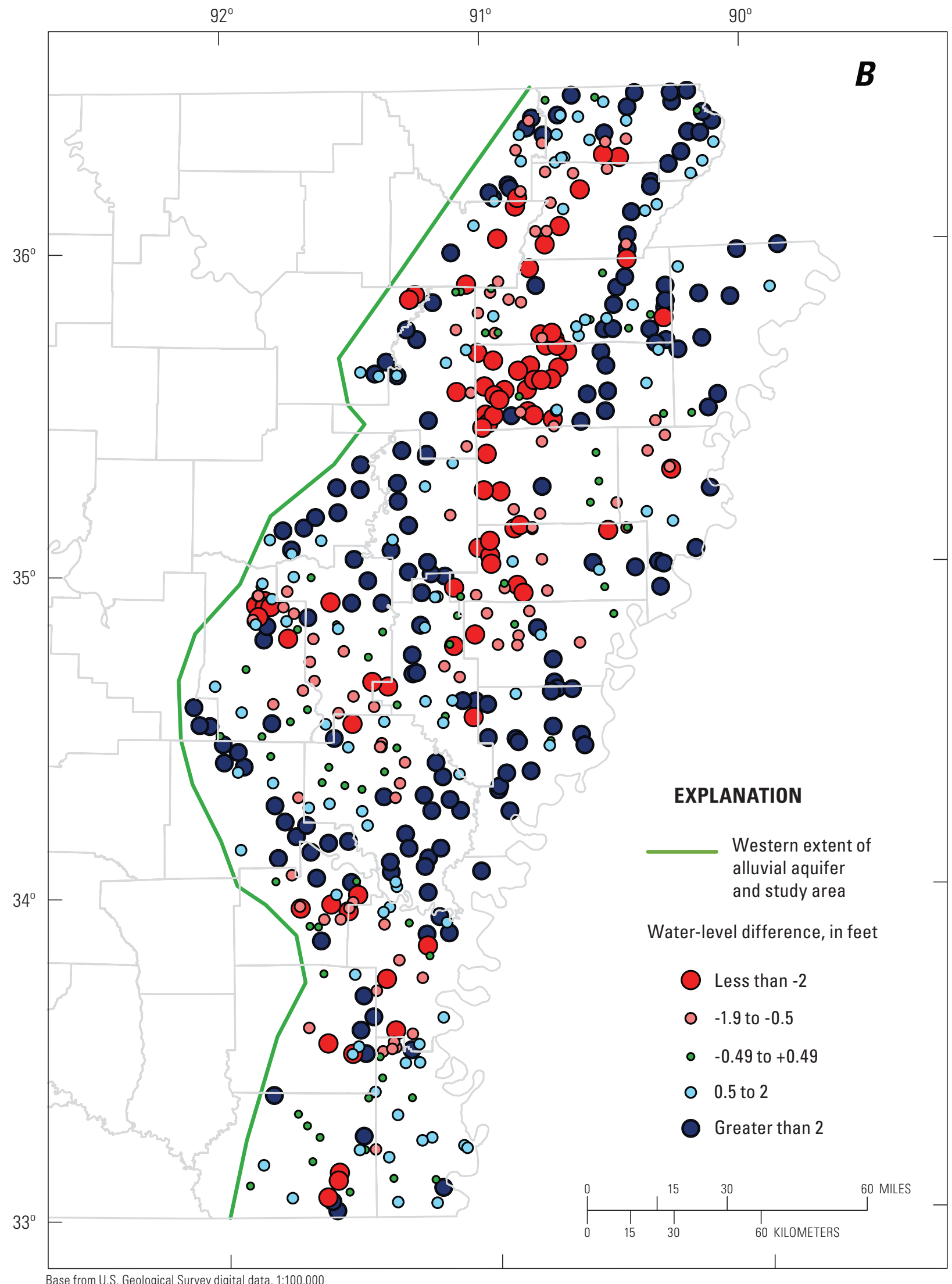

Figure 2. Four-year water-level difference in the Mississippi River Valley alluvial aquifer in eastern Arkansas $(A)$ 2004-8, and $(B)$ 200610.-Continued 


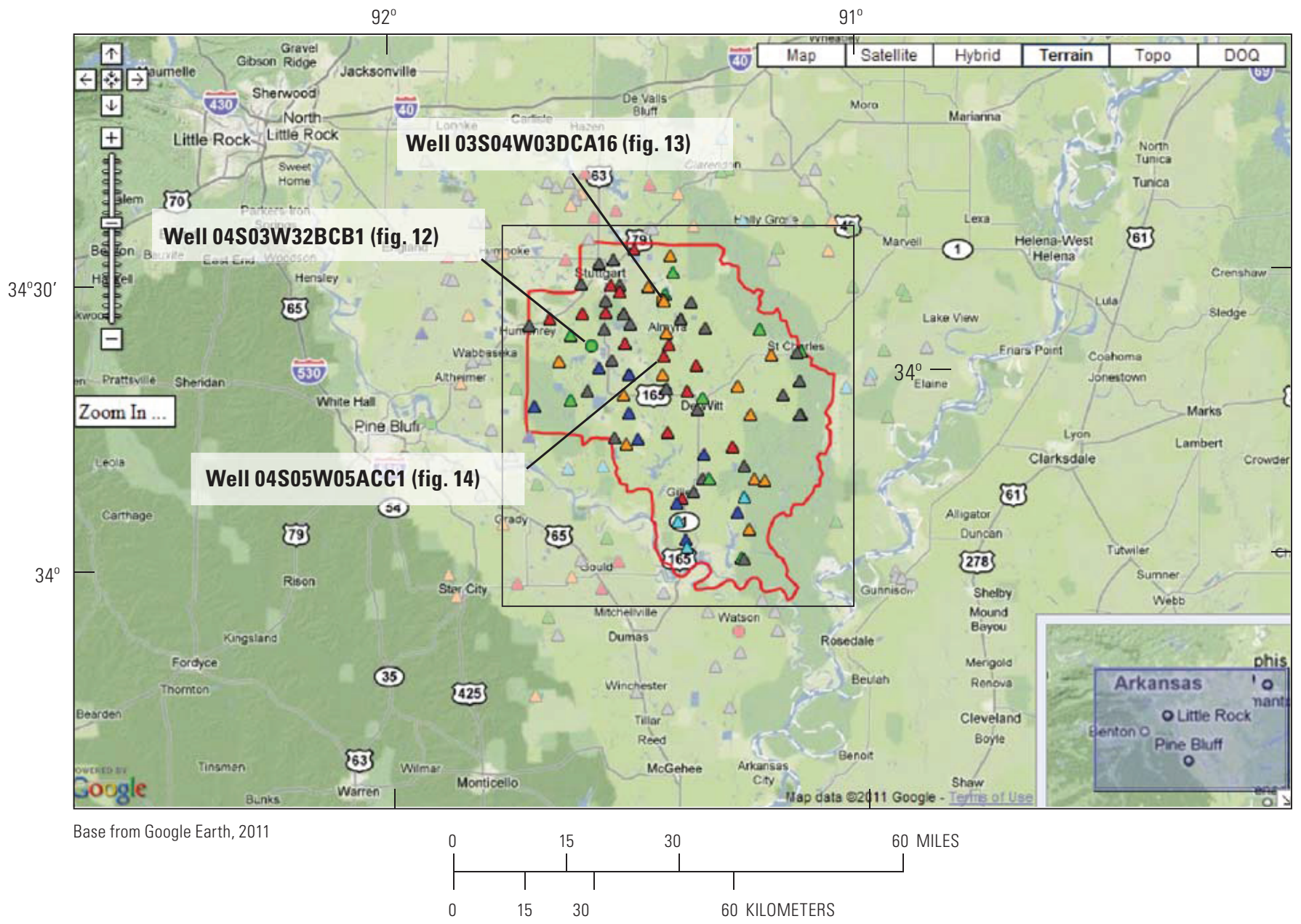

\section{EXPLANATION}

Percentile classes

(symbol color based on most recent measurement)

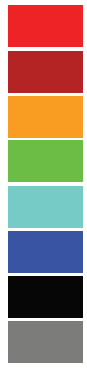

$\begin{array}{ll}\begin{array}{l}\text { Low } \\ \text { Less than } 10 \\ 10-24 \\ 25-75 \\ 76-90\end{array} & \text { Decreasesing } \\ \text { Greater than } 90 \\ \text { High } \\ \text { Not rated }\end{array}$

Arkansas County boundary

\section{Well type}

O Real time

Continuous

$\triangle$ Periodic measurements

Figure 3. Active water-level monitoring network in Arkansas County, Arkansas, and vicinity (U.S. Geological Survey, 2011). 


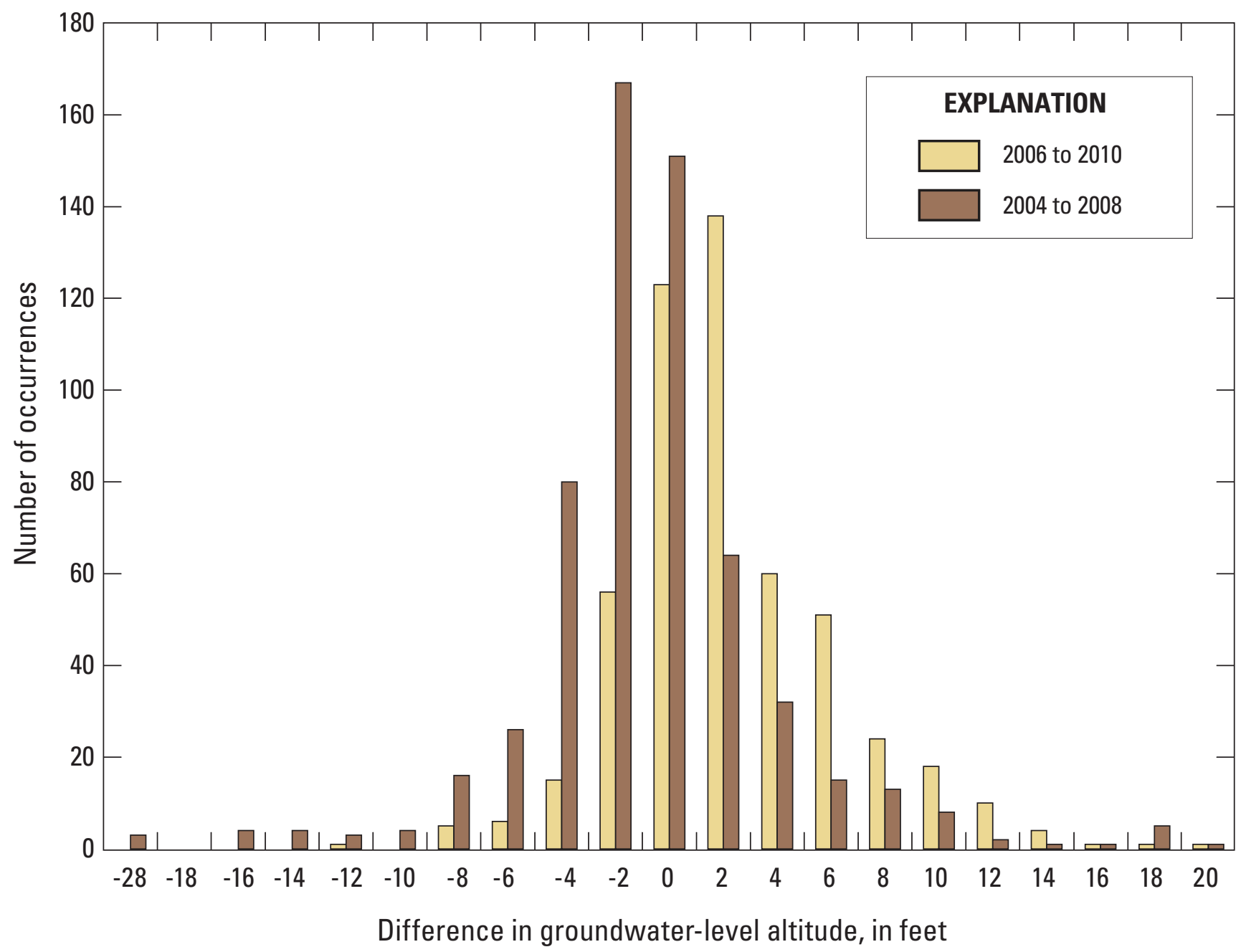

Figure 4. Differences in water-level altitudes for the alluvial aquifer in eastern Arkansas.

\section{Water Use and Conservation}

Observed water-level rises between 2006 and 2010 resulted, in part, from reduced water use. Record precipitation rates in 2009 likely resulted in decreased water use. A total of 7.87 million acre-ft (3.43 billion gallons) of groundwater was pumped from the alluvial aquifer in 2008 compared to a total of 0.17 million acre-ft (7.4 billion gallons) from the Sparta aquifer (Terrance E. Holland, U.S. Geological Survey, written commun., 2011). In 2009, total groundwater pumpage from the alluvial aquifer decreased by 22.9 percent to 6.07 million acre-ft (2.64 billion gallons), and from the Sparta aquifer by 17.6 percent to 0.144 million acre- $\mathrm{ft}$ ( 6.27 billion gallons) (Terrance E. Holland, U.S. Geological Survey, written commun., 2012). The five largest water users, by county, of all the water pumped from the alluvial aquifer in 2008 were Clay ( 9.2 percent), Poinsett ( 9.0 percent), Cross ( 7.8 percent), Jackson (5.6 percent), and Arkansas (5.4 percent)
Counties (fig. 5). A closer inspection of water use in Arkansas County (fig. 6) shows that water use peaked in 2000, and had the second largest water use by county ( 8.6 percent) from the alluvial aquifer with Poinsett County ranking first with 9.0 percent of the total water use (Terrance E. Holland, U.S. Geological Survey, written commun., 2011). Reasons for the subsequent decline in water use in Arkansas County from 2000 to 2009 may include use of water-conservation methods such as tailwater recovery reservoirs (fig. 7) and plastic polypipe (fig. 8) (Terrance E. Holland, U.S. Geological Survey, oral commun., 2011). Tailwater recovery reservoirs store runoff water from irrigation and precipitation from nearby farm fields, and water is recycled into the irrigation system. Polypipe is an efficient method of water application allowing for more accurate and even application of irrigation water. In addition to conservation practices, less waterintensive crops may have been planted or less water used because of higher energy costs, but data for these explanations were not analyzed for this study. 


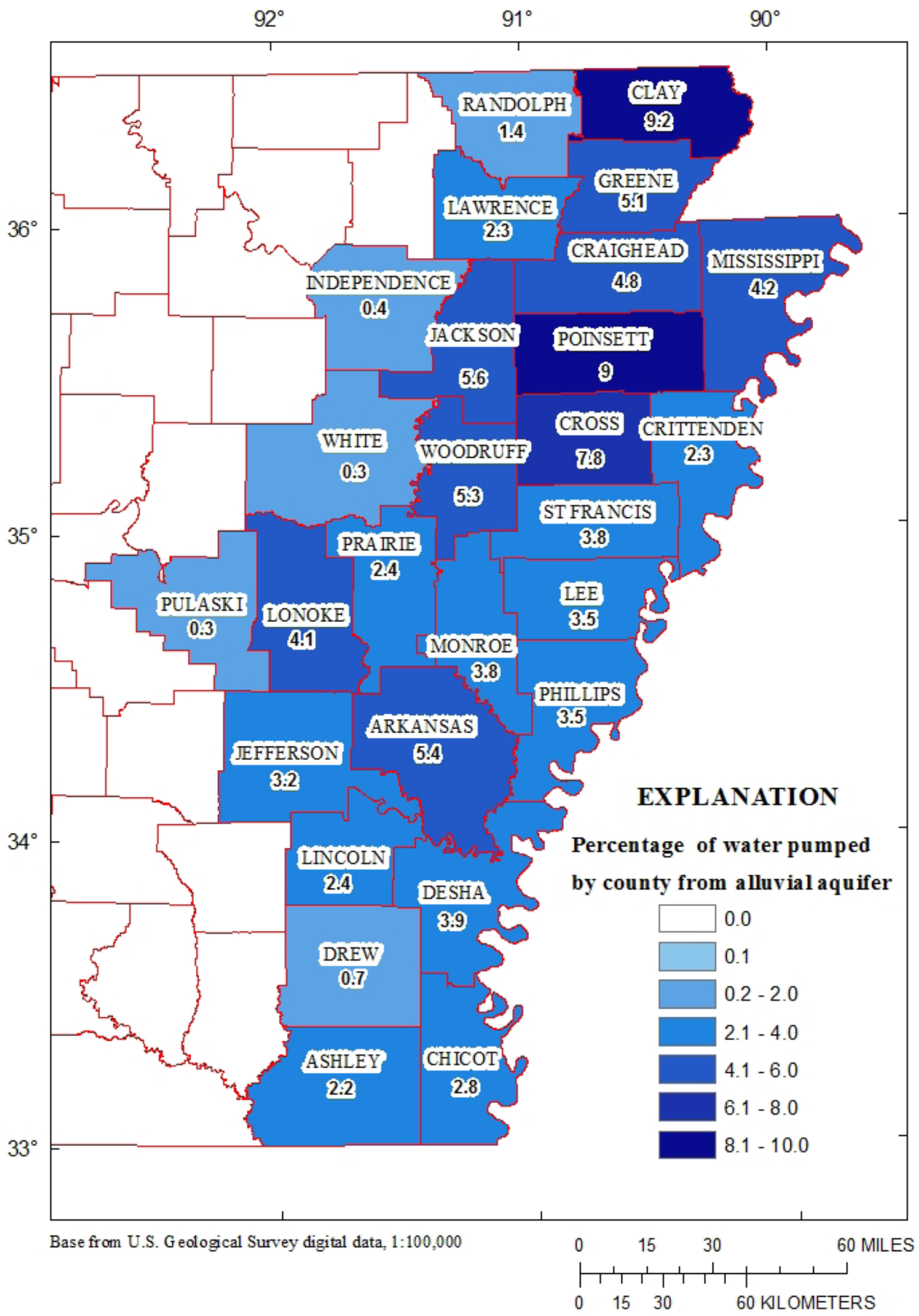

Figure 5. Percentage of water use in $\mathbf{2 0 0 8}$ from the alluvial aquifer in eastern Arkansas. 


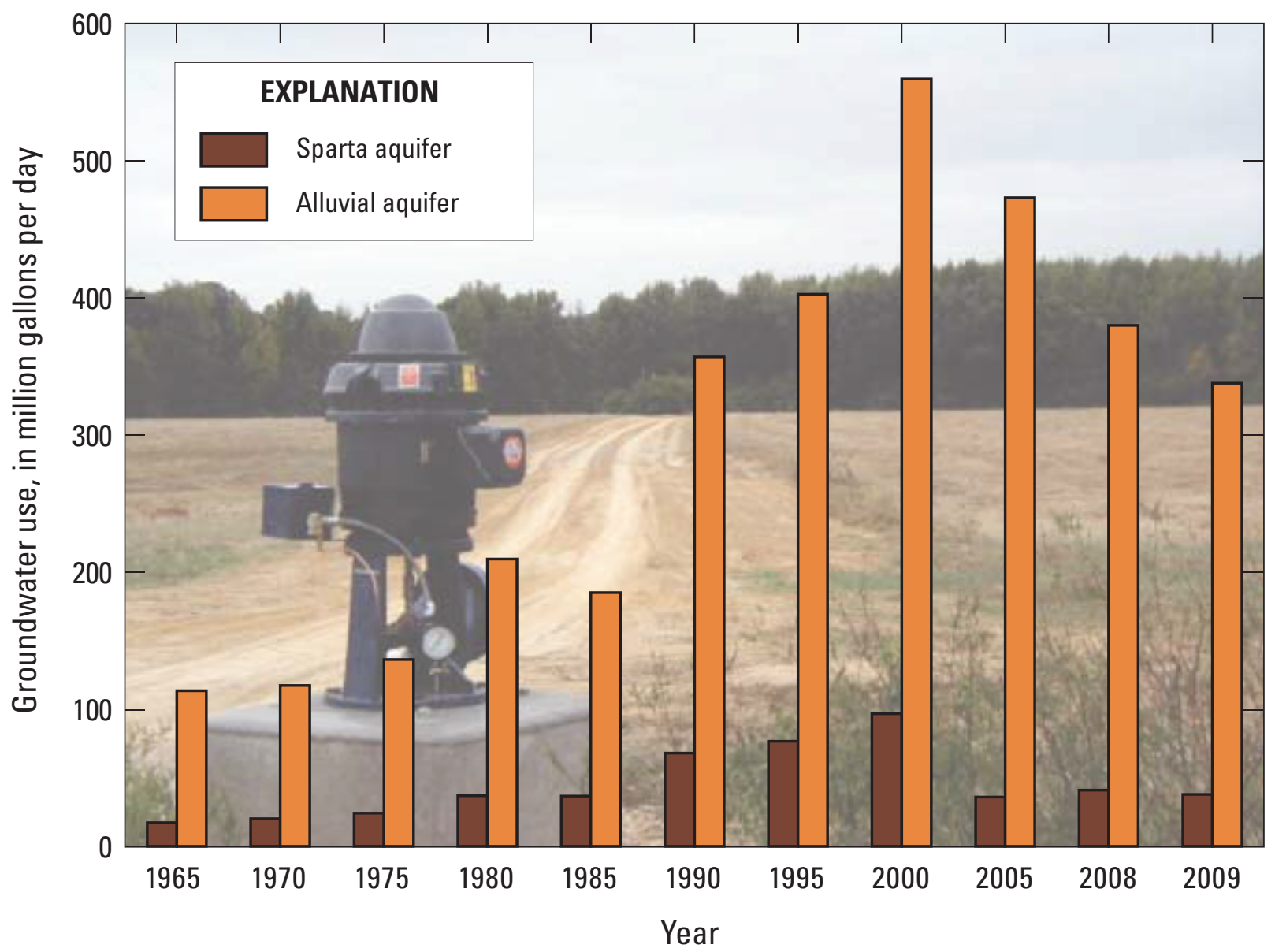

Figure 6. Groundwater use in Arkansas County, 1965 to 2009.

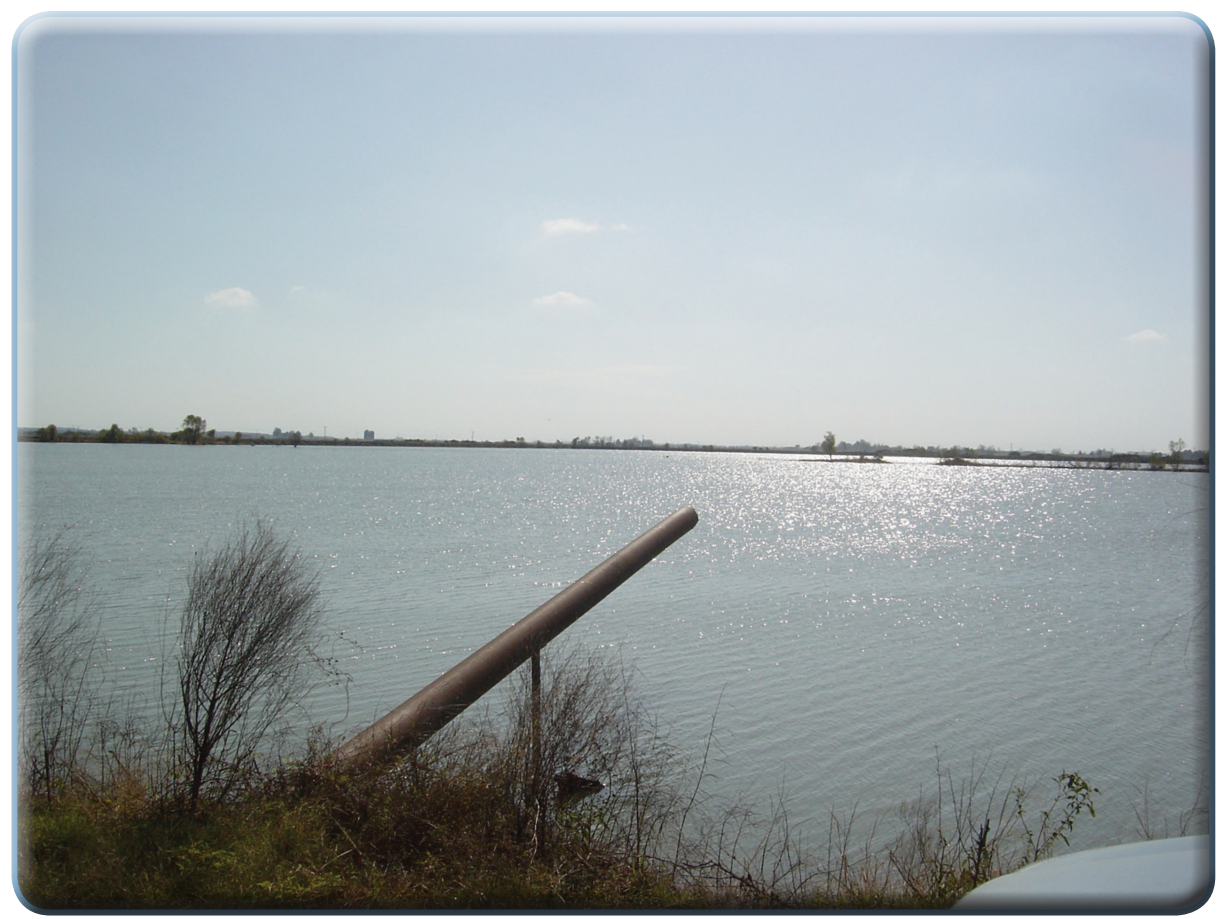

Figure 7. Tailwater recovery reservoir in Prairie County. 


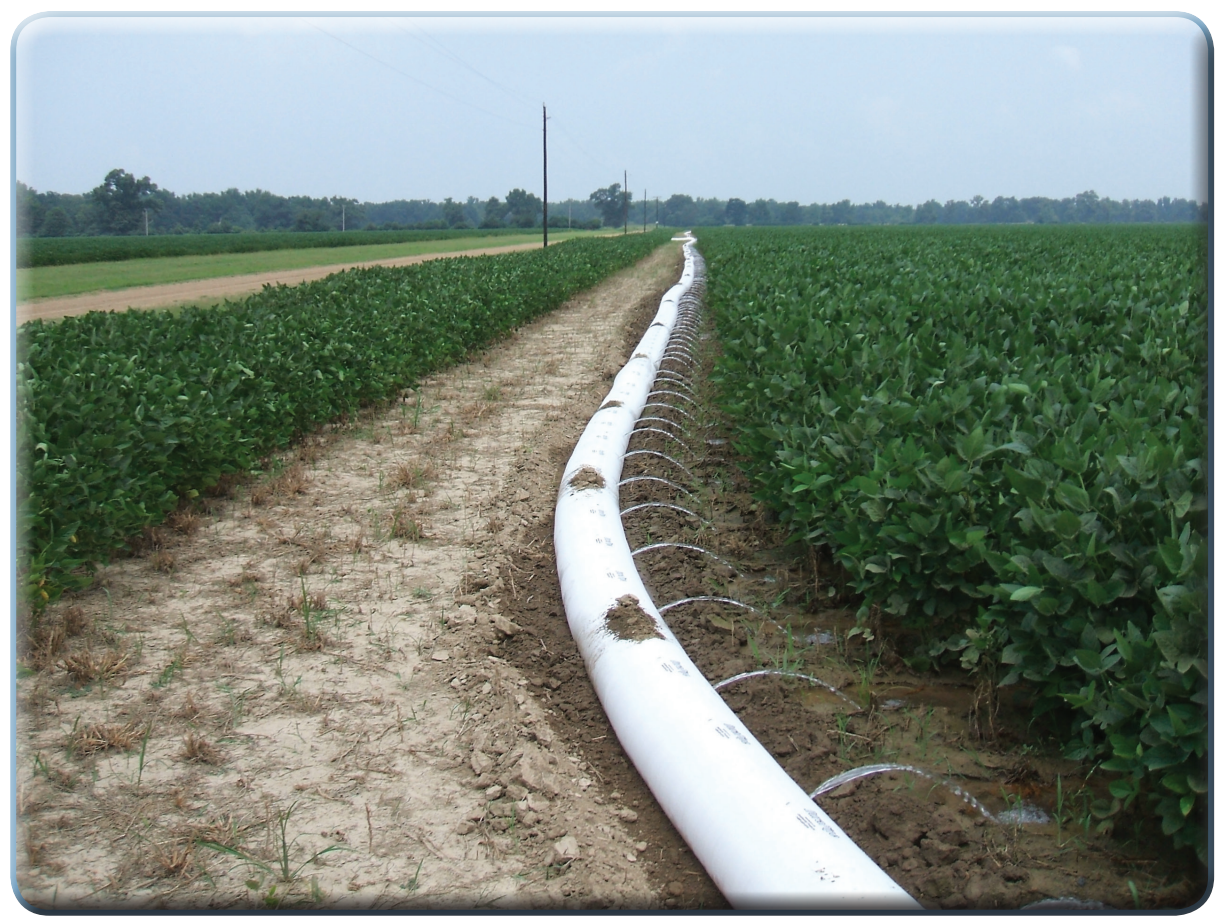

Figure 8. Polypipe used for irrigation of a soybean field.

\section{Groundwater Depletion}

Although conservation measures have resulted in declines in pumping in Arkansas County since 2000, a large component of the decline in pumping is the result of farmers being unable to pump sufficient water from the alluvial aquifer. Waterlevel declines have caused reduced saturated thickness in the alluvial aquifer, which translates into reduced transmissivity and ultimately less flow to wells, making groundwater pumping uneconomical and impractical in some areas (Dennis Carman, White River Irrigation District, oral commun., 2011). Using a groundwater-flow model of the northern part of the alluvial aquifer (Czarnecki, 2010), saturated thickness in 2010 was calculated by subtracting the altitude of the bottom of the aquifer (fig. 9) from the simulated water-level altitude in 2010 (fig. 10). The 2010 simulated saturated thickness in Arkansas County contained many areas that are $20 \mathrm{ft}$ or less; some parts of the alluvial aquifer in Arkansas County were simulated as dry in 2010 (fig. 11). 


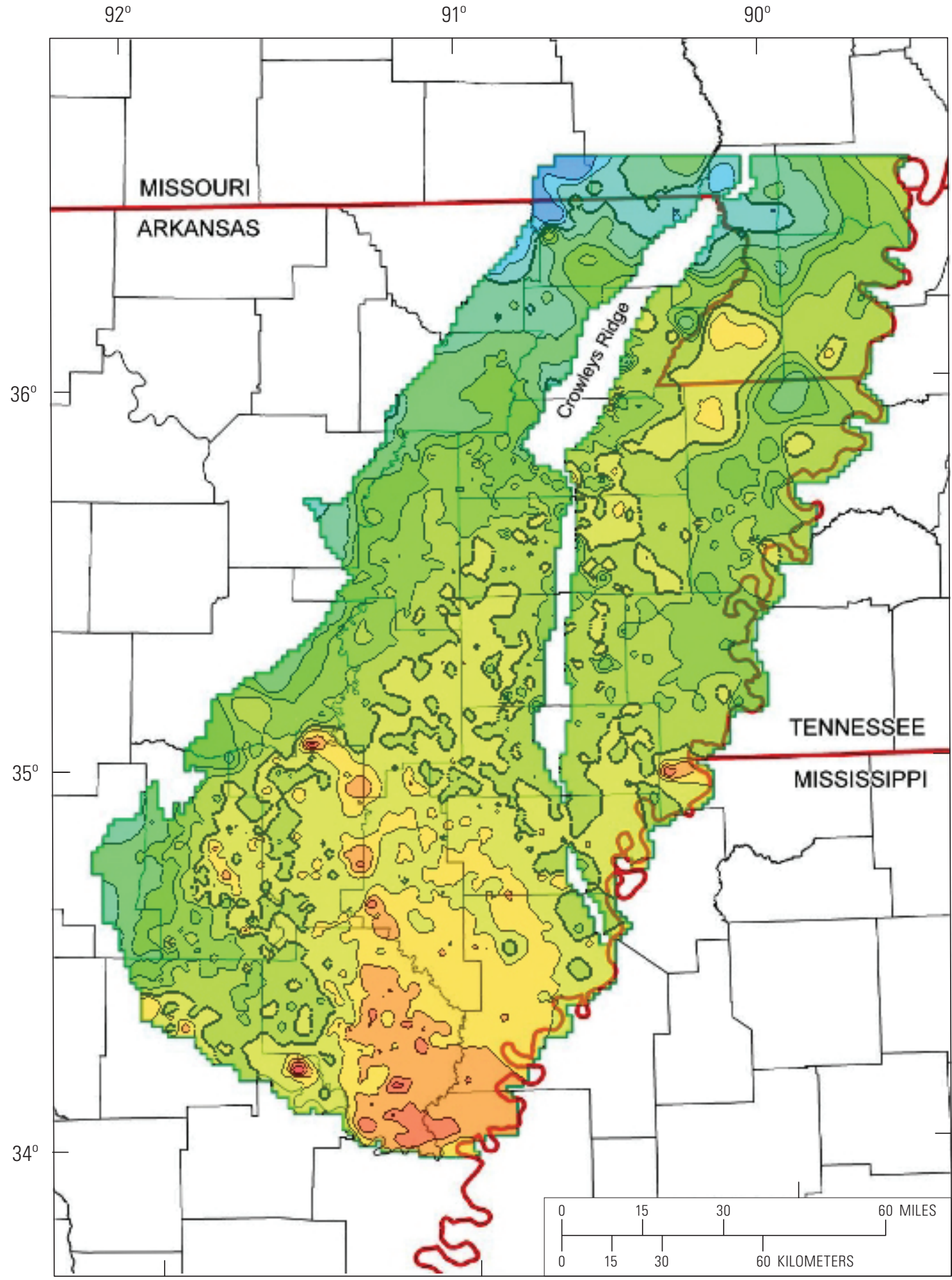

\section{EXPLANATION}

Simulated altitude of the bottom of the alluvial aquifer, in feet above Geodetic Vertical Datum of 1929

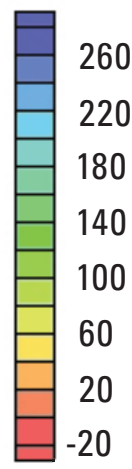

Base from U.S. Geological Survey digital data, 1:100,000

Datum is National Geodetic Vertical Datum of 1929 .

Figure 9. Simulated altitude of the bottom of the northern part of the alluvial aquifer from the model of Czarnecki (2010). 


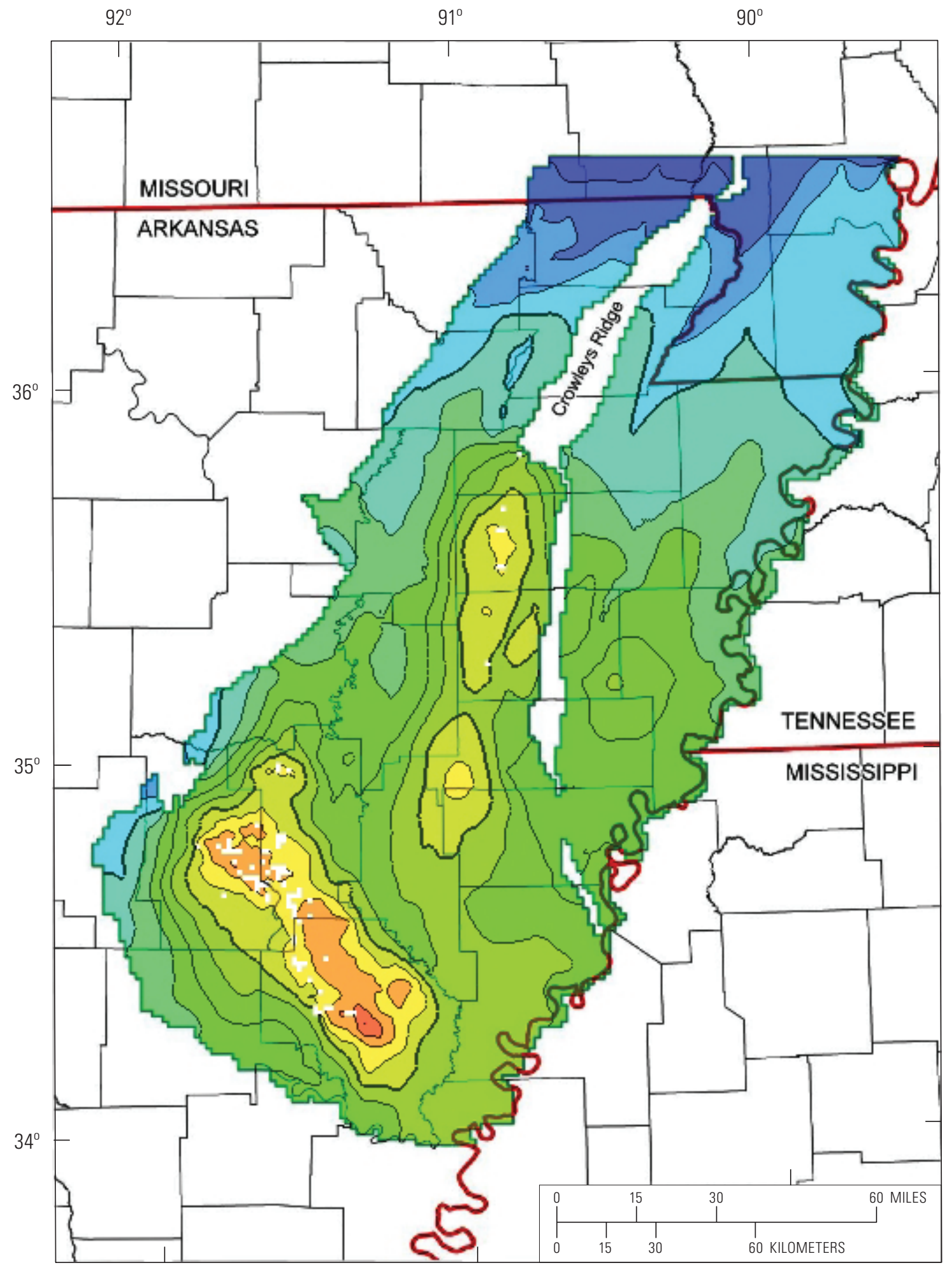

\section{EXPLANATION}

Simulated water-level altitude, in feet above Geodetic Vertical Datum of 1929

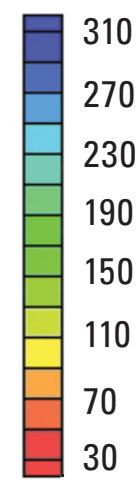

Base from U.S. Geological Survey digital data, 1:100,000 Datum is National Geodetic Vertical Datum of 1929.

Figure 10. Simulated water-level altitude in 2010. 


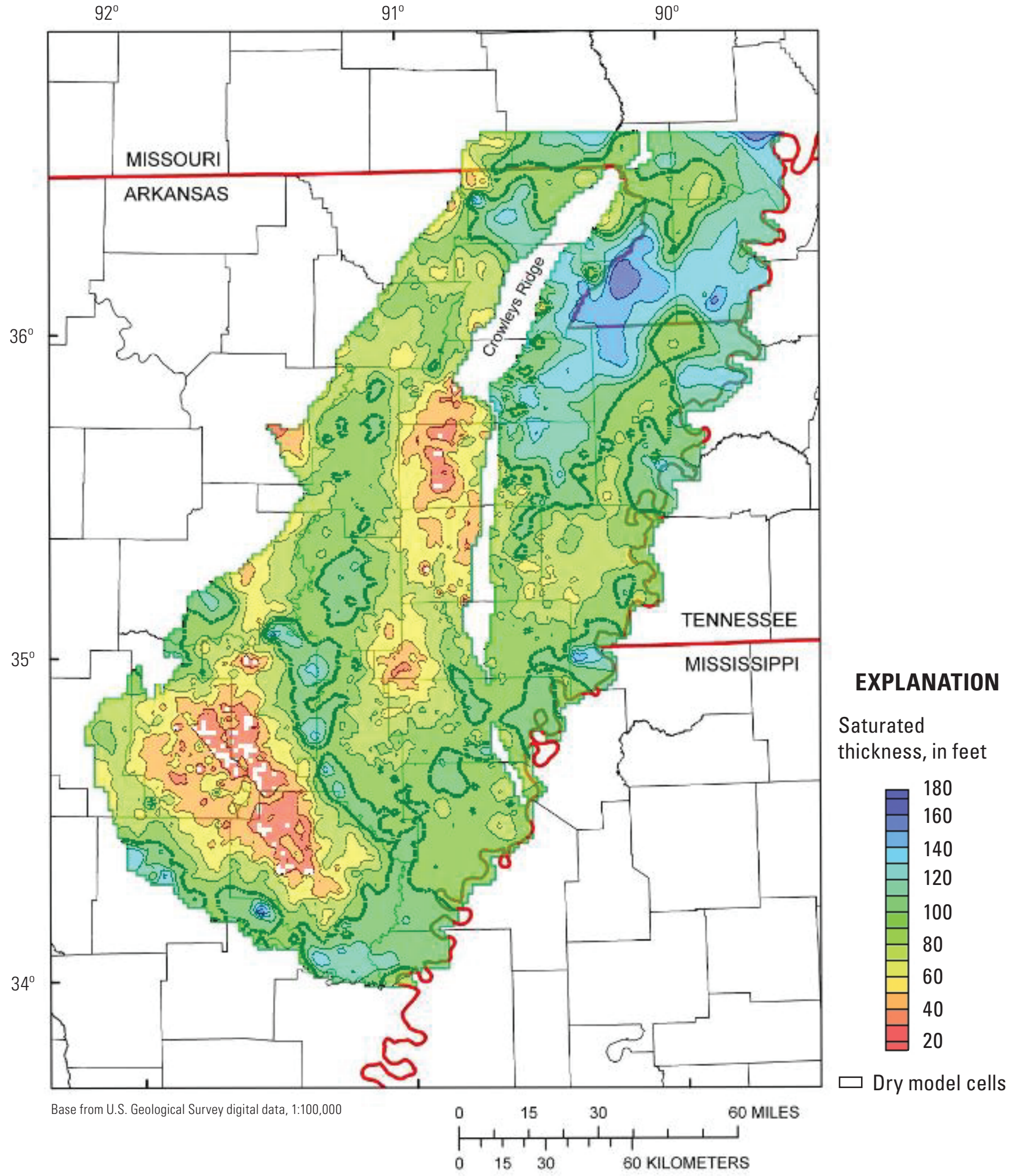

Figure 11. Simulated thickness for the Mississippi River Valley alluvial aquifer, 2010. 


\section{Long- and Short-Term Water-Level Changes: A Case for Continuous Monitoring}

Water-level monitoring is essential for evaluating trends in water levels with time. Water-level declines have been observed in the alluvial aquifer in Arkansas County since at least 1937 (fig. 12). Water-level declines vary with time and location. Continuous water-level data, as exemplified by hydrographs (figs. 13 and 14) from the 25 wells continuously monitored in Arkansas, provide a better understanding of the seasonal and long-term trends in water levels. To assess the trends in these data, linear regression analysis was used to generate regression lines (Helsel and Hirsch, 1992). This analysis assumes that water-level altitude is dependent only on one variable (time). The general equation for each regression line can be written as

$$
y=m x+b
$$

where

$$
\begin{aligned}
& y \quad \text { is the dependent variable (water-level altitude, } \\
& \text { in feet), } \\
& \text { is the slope (rate of water-level change with } \\
& \text { time, in feet per year), } \\
& \text { is the independent variable (time, in years), } \\
& \text { and } \\
& \text { is the y-axis intercept (water-level altitude, in } \\
& \text { feet). }
\end{aligned}
$$

The slope and y-axis intercept are estimated for each regression line so as to minimize the difference between the observed and predicted water-level altitudes. Despite the seasonal effects, regression lines through the continuous water-level data for periods 2000-6, 2006-9, and 2009-11 show declines (fig. 13). In 2010, water levels appear to have rebounded somewhat, possibly as a result of wetter conditions in 2009 coupled with less groundwater use. Furthermore, the average rate of water decline following the wettest year (2009) was only $0.02 \mathrm{ft} / \mathrm{yr}$ from 2009 to 2011, compared to a decline of $0.22 \mathrm{ft} / \mathrm{yr}$ from 2000 to 2006 and a decline of $0.34 \mathrm{ft} / \mathrm{yr}$ from 2006 to 2009 .

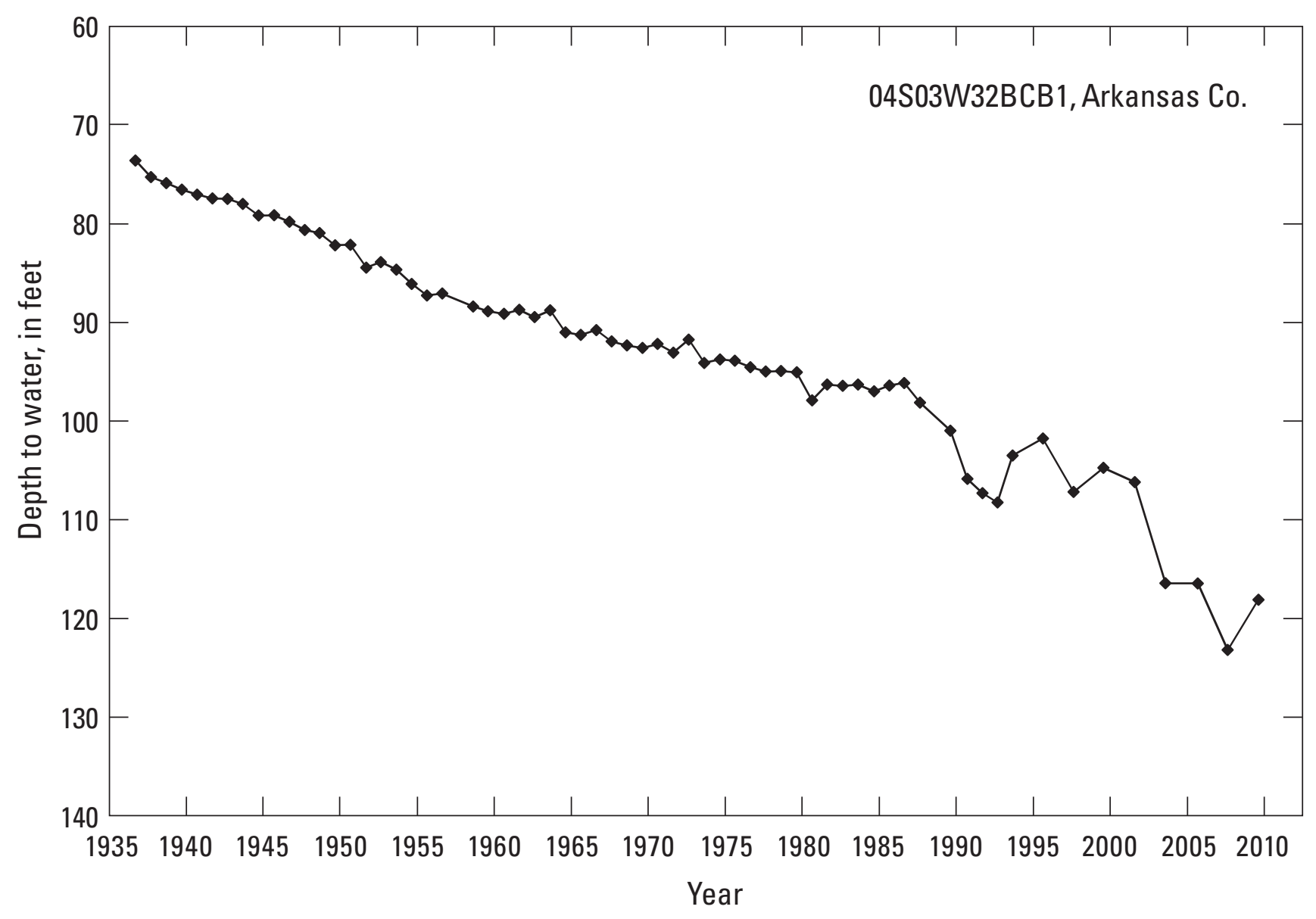

Figure 12. Periodic depth-to-water measurements made in Arkansas County well 04S03W32BCB1 completed in the alluvial aquifer, 1937 to 2010 (see figure 3 for location). 


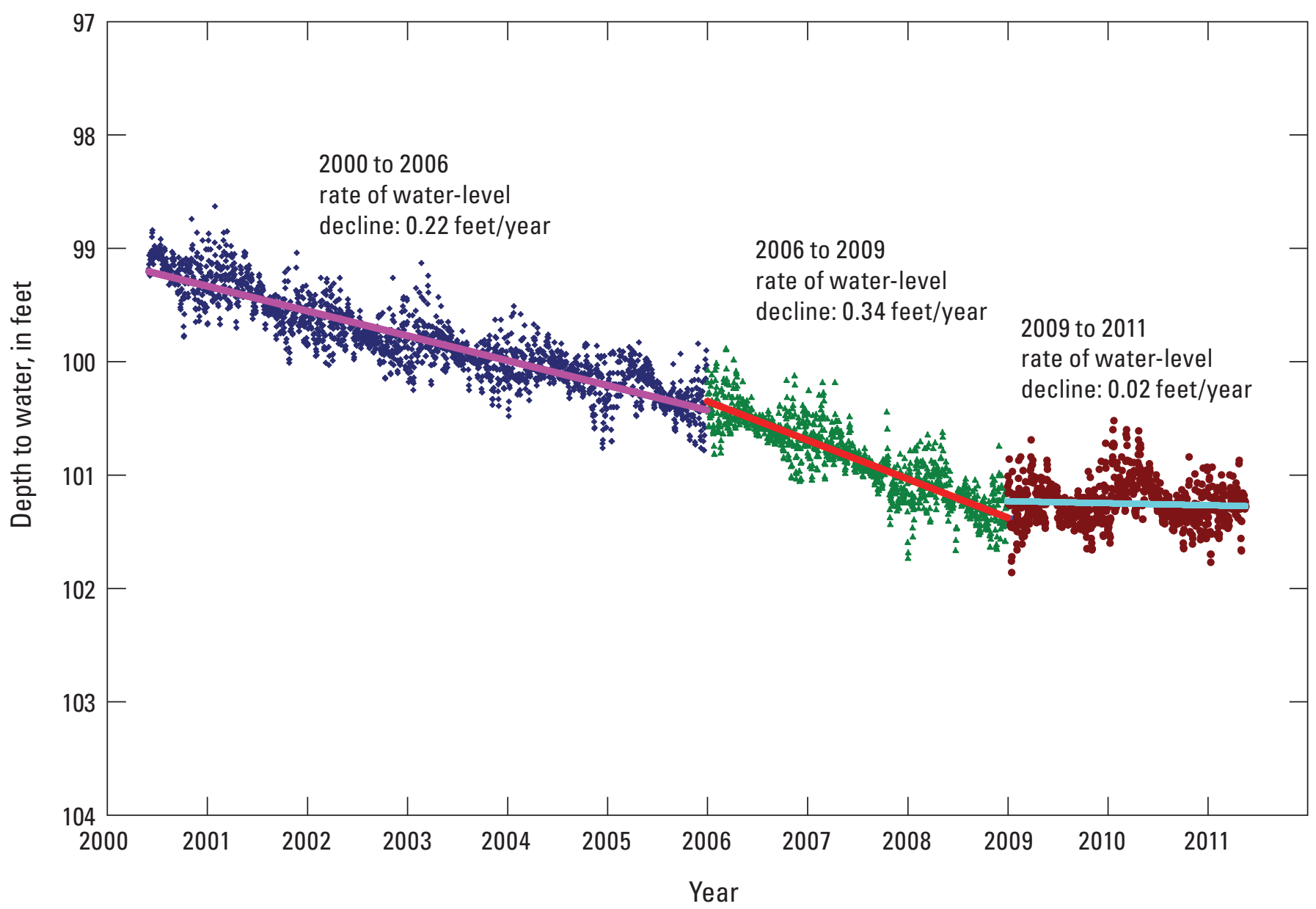

Figure 13. Continuous depth-to-water measurements made in Arkansas County well 03S04W03DCA16, completed in the alluvial aquifer, 2000 to 2011 (see figure 3 for location).

As wells in some areas produce less water from the alluvial aquifer, reliance on the deeper Sparta aquifer occurs to make up for some, but not all, of the unmet demand (fig. 6). Although pumping decreased in the alluvial and Sparta aquifers between 2000 and 2005, the decrease in the alluvial aquifer pumping was larger. From 2000 to 2005, pumping in Arkansas County from the alluvial aquifer decreased by 86.64 million gallons per day $(\mathrm{Mgal} / \mathrm{d})$, or 15.5 percent reduction from that aquifer compared to a reduction of $60.72 \mathrm{Mgal} / \mathrm{d}$ from the Sparta aquifer (a 62.8 percent reduction from 2000 rates for that aquifer). However, from 2005 to 2008, pumping from the alluvial aquifer decreased 93.08 Mgal/d (28.6 percent) compared to an increase in pumping from the Sparta aquifer of 5.02 Mgal/d (5.2 percent).

Drawdown in the Sparta aquifer has been considerable as indicated by the hydrograph for well 04S05W05ACC1 in Arkansas County (fig. 14). Periodic measurements were made in this well between 1948 and 2005, and during this time water levels dropped about $116 \mathrm{ft}$. Because the measurements were not sufficiently frequent, seasonal water-level fluctuations could not be observed. Beginning in August 2007, frequent, hourly water-level measurements were recorded in the well and showed that annual changes in water levels generally exceeded $50 \mathrm{ft}$. Water levels in 2009 (the wettest year on record) fluctuated only $40 \mathrm{ft}$, compared to $73 \mathrm{ft}$ in 2010 (14th driest year on record). Without continuous water-level measurements, a comparison of the effect of wet and dry years on water-level changes would have been less accurate. Although the well is not pumped, it does respond to waterlevel changes in the Sparta aquifer caused largely by seasonal pumping from irrigation wells located about 1 to 2 miles away. Periodic measurements made in well 04S05W05ACC1 confirm the accuracy of the continuous measurements

(fig. 14); however, without the hourly continuous measurements there would have been little incentive to perform the confirmatory, periodic measurements because the cyclic water-level changes caused by seasonal pumping would have gone unobserved. Real-time continuous water-level measurements provide a better representation of the waterlevel changes occurring within the aquifer, which then can be evaluated in the context of potential causes such as seasonal changes in pumping rates or wetter/drier climatic conditions. 


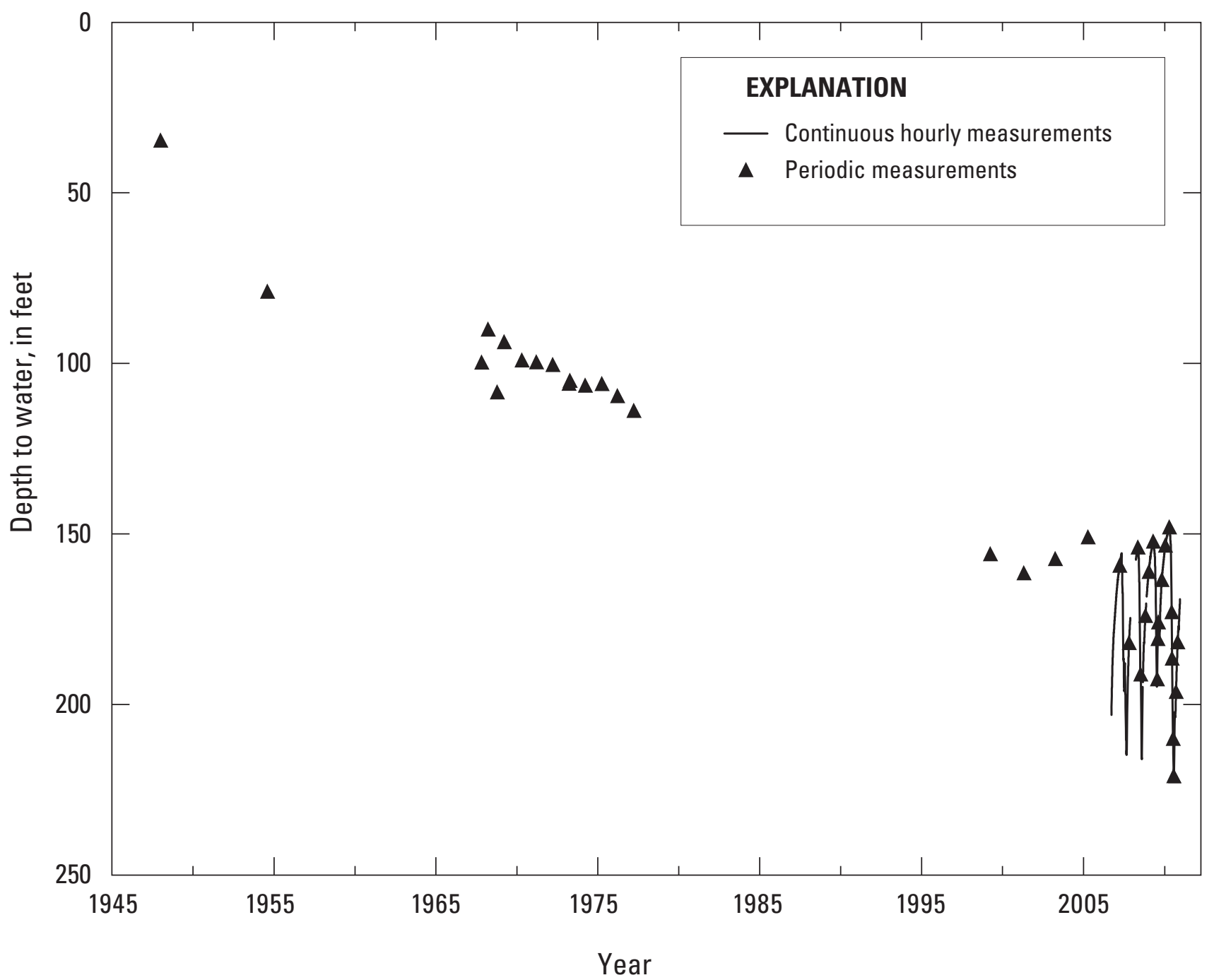

Figure 14. Hydrograph of Arkansas County well 04S05W05ACC1 completed in the Sparta aquifer showing substantial decline in water levels from 1948 to 2010 (see figure 3 for location).

In addition, real-time continuous water-level measurements generally are obtained at a reduced cost per measurement compared to periodic measurements made manually and allow for offsite evaluation of measurement equipment and well conditions without having to visit the well site.

\section{Future Water-Level Monitoring}

The water-level monitoring network is a vital component for understanding and managing the groundwater resources in Arkansas. Although the program has been effective in providing reliable water-level data, improvements are possible. One such improvement would be to increase the distribution of continuous monitoring wells, particularly in counties with Critical Groundwater Areas (Arkansas Natural Resources Commission, 2011) that pump groundwater from the alluvial or Sparta aquifers. By increasing the distribution of continuous monitoring wells, a better understanding of how quickly water levels in the alluvial and Sparta aquifers respond to climate variability and changes in water use will be possible - particularly the anticipated reductions in groundwater use associated with the Grand Prairie Area Demonstration Project (U.S. Army Corps of Engineers, 2012), which will divert water from the White River to supply irrigation water to Arkansas, Prairie, and Lonoke Counties. As demands on groundwater resources continue, it will be more important to continuously monitor changes in water levels, which will provide water managers with accurate and timely information to help protect these vital resources for future generations. 


\section{Summary}

Water levels in wells completed in the Mississippi River Valley alluvial aquifer and the Sparta aquifer in eastern Arkansas respond to variability associated with annual precipitation. The wettest year on record in Little Rock, Arkansas, occurred in 2009 with 81.79 inches of precipitation compared to an average of 47.1 inches per year (in/yr). In contrast, 2005 and 2010 were the 7th and 14th driest years on record with 34.55 and $36.52 \mathrm{in} / \mathrm{yr}$, respectively. This variability in precipitation was reflected in water-level altitude changes between 2004 and 2008 and 2006 and 2010 . Generally, drier conditions between 2004 and 2008 led to an average decline in water levels in eastern Arkansas of 1.62 feet (ft), whereas, wetter conditions between 2006 and 2010 led to an average rise in water levels of $1.36 \mathrm{ft}$. Drier periods likely result in less recharge compared to wetter periods. Groundwater use from the alluvial aquifer peaked in 2000 and has been on the decline, in part, because of conservation measures and substantial reduction in aquifer saturated thickness. Groundwater-flow model results show some areas of the alluvial aquifer simulated as dry in 2010, resulting in reduced capacity of the alluvial aquifer to produce water in those areas. Periodic and real-time continuous water-level data show substantial changes in the alluvial and Sparta aquifers. However, real-time continuous water-level measurements allow for a more complete and accurate assessment of water-level changes resulting from the effect of variability in precipitation and water use than do periodic water-level measurements.

\section{References Cited}

Arkansas Natural Resources Commission, 2011, The facts about critical ground water designation: Arkansas Natural Resources Commission, accessed February 15, 2012, at http://www.arkansas.gov/awwcc/gw_designation graphic.pdf.
Czarnecki, J.B., 2010, Groundwater-flow assessment of the Mississippi River Valley alluvial aquifer of northeastern Arkansas: U.S. Geological Survey Scientific Investigations Report 2010-5210, 33 p.

Helsel, D.R., and Hirsch, R.M., 1992, Statistical methods in water resources: New York, N.Y., Elsevier Science Publishing Co., 522 p.

National Oceanic and Atmospheric Administration, 2011, NOAA: 2010 tied for warmest year on record, accessed February 15, 2012, at http://www.noaanews.noaa.gov/ stories2011/20110112_globalstats.html.

National Weather Service, 2011, Climate statistics for the Little Rock area: National Weather Service, accessed January 11, 2011, at http://www.srh.noaa.gov/images/lzk/ pdf/clilit.pdf.

National Weather Service, 2012, Little Rock yearly climate summary (2009): National Weather Service, accessed January 19, 2012, at http://www.srh.noaa.gov/lzk/?n=2009. htm.

Schrader, T.P., 2010, Water levels and selected water-quality conditions in the Mississippi River Valley alluvial aquifer in eastern Arkansas, 2008: U.S. Geological Survey Scientific Investigations Report 2010-5140, 71 p., 2 plates.

U.S. Army Corps of Engineers, 2012, Grand Prairie area demonstration project: U.S. Army Corps of Engineers, Memphis District, accessed January 25, 2012, at http://www.mvm.usace.army.mil/grandprairie/overview/ default.asp.

U.S. Geological Survey, 2011, Groundwater watch: Arkansas County, Arkansas: U.S. Geological Survey, accessed April 28, 2011, at http://groundwaterwatch.usgs.gov/countymaps/ AR_117.html.

U.S. Geological Survey, 2012, Aggregate Water-Use Data System (AWUDS) of USGS, accessed February 15, 2012, at http://water.usgs.gov/watuse/wuawuds.html. 
